\title{
EVALUASI IMPLEMENTASI PERDA NOMOR 6 TAHUN 2011 TENTANG PERLINDUNGAN ANAK YANG HIDUP DI JALAN
}

Agustinus Pas ${ }^{1} *$, Badrun Kartowagiran ${ }^{1}$

${ }^{1}$ Universitas Negeri Yogyakarta

${ }^{1}$ Jl. Colombo No. 1, Depok, Sleman 55281, Yogyakarta, Indonesia

* Corresponding Author. Email: imanuel.igcp@gmail.com,

\begin{abstract}
Abstrak
Penelitian ini bertujuan untuk: (1) mendeskripsikan implementasi Perda No 6 Tahun 2011 Tentang Perlindungan Anak yang Hidup di Jalan oleh Dinas Sosial DIY; (2) mendeskripsikan hambatan-hambatan dalam memenuhi hak dan kebutuhan anak jalanan; (3) dan mendeskripsikan solusi dalam mengatasi hambatan yang ditemukan. Penelitian ini merupakan penelitian evaluasi dengan pendekatan deskriptif kualitatif dan kuantitatif menggunakan model evaluasi kesenjangan. Responden penelitian terdiri atas staf perlindungan anak, pengasuh Rumah Perlindungan Sosial dan Lembaga Kesejahteraan Sosial Anak, dan anak jalanan. Pengumpulan data dilakukan melalui wawancara, observasi, kuesioner, dan dokumentasi. Keabsahan data kualitatif menggunakan uji kredibilitas, transferabilitas, dependabilitas, dan konfirmabilitas. Validitas instrumen menggunakan validitas isi, dan estimasi reliabilitas angket menggunakan Cronbach Alpha dengan koefisien sebesar 0,75. Data dianalisis secara deskriptif. Hasil penelitian menunjukkan bahwa Dinas Sosial telah memenuhi hak dan kebutuhan anak jalanan dengan baik, kecuali pemenuhan hak identitas. Tugas Dinas Sosial selanjutnya adalah memenuhi hak identitas anak jalanan melalui kerjasama yang berkelanjutan dengan semua pihak terkait.
\end{abstract}

Kata kunci: perlindungan, pemenuhan hak dan kebutuhan, anak jalanan.

\section{AN EVALUATION OF THE IMPLEMENTATION OF REGIONAL REGULATION NUMBER 6 OF 2011 ABOUT STREET CHILDREN PROTECTION}

\begin{abstract}
This research aims to: (1) describe the implementation of Regional Regulation Number 6 of 2011 about Street Children Protection (the fulfillment of children rights) was realized by Social Office of DIY, (2) describe the obstacles found by the Social Office of DIY in fulfill the rights and the needs of street children, (3) and to describe the solution to overcome the obstacles found. This was an evaluation research that used quantitative and quantitative descriptive approach with the discrepancy evaluation model. The respondents in this research consisted of the staff of street children protection, caretakers in social protection houses and child social welfare institutions, and street children. Data collection was done through interviews, observation, questionnaire and documentation. The validity and reliability of qualitative data was measured through credibility, transfer-ability, dependability, and confirm-ability testing. Research instrument validity was measured through content validity and the testing of questionnaire instrument is through Cronbach Alpha with a coefficient of 0.75 . The results of this research show that the rights and needs of street children has fulfill well by Social Office, except in fulfilling the right of identity. The next task of the Social Office is to fulfill the rights of the street children's identity through ongoing collaboration with all relevant agencies.
\end{abstract}

Keywords: protection, fulfillment of rights and needs, street children 


\section{PENDAHULUAN}

Seiring dengan perkembangan zaman, berkembang pula masalah sosial yang dihadapi manusia. Masalah sosial dapat dipahami sebagai kondisi yang terlahir dari sebuah keadaan masyarakat yang tidak ideal. Dengan kata lain, kunci masalah sosial terletak pada kondisi yang tidak diharapkan, dan oleh sebab itu diperlukan upaya untuk melakukan perbaikan dan perubahan (Soetomo, 2013, p. 9). Anak jalanan merupakan salah satu contoh masalah sosial yang hadir bersamaan dengan persoalan sosial lainnya dalam realitas perkembangan zaman. Anak jalanan atau yang secara eufemistis terkadang disebut sebagai anak yang mandiri sesungguhnya adalah anak-anak yang terisolasi secara sosial (Nugroho, 2004, p. 17). Menurut laporan hasil pemutakhiran data anak jalanan yang dilakukan oleh DINSOS DIY tahun 2014, jumlah anak jalanan di DIY sebanyak 220 anak yang terdiri dari 73, 64\% laki-laki/162 anak dan 26, $36 \%$ perempuan/58 anak. Latar belakang munculnya anak jalanan disebabkan melalui beberapa faktor seperti kondisi ekonomi, kurangnya perhatian orang tua, situasi rumah yang tidak kondusif bagi anak, eksploitasi, mencari teman, dan berbagai alasan lainnya.

Eksploitatif, rentan dengan berbagai kekerasan, dan marginal (Rafi, Ali, \& Aslam, 2012, p. 1) adalah istilah-istilah yang kemudian terbilang relevan dalam merepresentasikan kondisi dan kehidupan mereka. Eksploitatif karena mereka memiliki posisi tawar-menawar yang sangat lemah dan cenderung menjadi objek perlakuan yang sewenang-wenang dari ulah preman atau oknum aparat yang kurang bertanggung jawab. Rentan dengan berbagai kekerasan fisik dan mental, karena tidak memiliki perlindungan, pengawasan dan arahan dari orang tua atau yang lebih dewasa (BoakyeBoaten, 2016). Adapun disebut marginal karena mereka melakukan pekerjaan yang tidak jelas jenjang kariernya, kurang dihargai, dan tidak menjanjikan prospek atau perubahan ke arah masa depan yang lebih baik. Berdasarkan hasil pengamatan dan kajian di lapangan, pengamat sosial, dan pemerhati masalah anak jalanan, Surbakti dkk (Suyanto, 2010, p. 186) membedakan anak jalanan ke dalam tiga kelompok yakni; children on the street, children of the street, dan children from families of the street.

Children on the street, adalah anakanak yang mempunyai kegiatan ekonomi seba- gai pekerja anak di jalan, namun masih mempunyai hubungan yang kuat dengan orang tua. Mereka bertugas untuk membantu memperkuat ekonomi keluarga karena beban atau tekanan kemiskinan yang tidak dapat diselesaikan sendiri oleh orang tua. Children of the street, yakni anak-anak yang berpartisipasi penuh di jalanan, baik secara sosial, maupun ekonomi. Banyak di antara mereka adalah anakanak yang karena suatu sebab seperti kekerasan, kurangnya perhatian dan kasih sayang, lari atau pergi dari rumah. Sedangkan Children from families of the street, adalah anak-anak yang berasal dari keluarga yang hidup di jalanan. Salah satu ciri penting dari anak-anak dalam kategori ini adalah kehadirannya di jalanan sejak usia bay, atau bahkan sejak masih dalam kandungan. Kategori ini sangat mudah ditemui di bebagai kolong jembatan, rumah-rumah liar sepanjang rel kereta api, taman dan berbagai tempat umum lainnya (Lusk, 1989, p. 5).

Sebagai salah satu masalah sosial, isu tentang anak jalanan memang belum sepopuler isu mengenai kemiskinan. Walaupun demikian, akhir-akhir ini sejak situasi krisis mulai merambah ke beberapa wilayah, kesadaran dan perhatian terhadap anak jalanan semakin meningkat. Mengenai hal ini Bapak Subakir, Koordinator anak jalanan di Dinas Sosial DIY (Wawancara: 02 Mei 2016) menyetujui bahwa keberadaan anak jalanan tidak lagi dipahami sebagai kasus yang insidental atau sementara, tetapi telah dipandang dan diakui sebagai fenomena sosial yang membutuhkan perhatian yang serius dari berbagai pihak, baik dari pemerintah, lembaga-lembaga sosial, dan tentunya masyarakat pada umumnya, sebagaimana diakui. Di samping itu, sebagai kondisi sosial yang tidak sesuai dengan harapan masyarakat atau kondisi yang tidak dikehendaki, sejatinya menjadi dorongan bagi setiap orang, kelompok masyarakat, lembaga sosial, dan tentunya pemerintah untuk mengubah dan memperbaikinya (Soetomo, 2013, p. 21). Agar lebih berdaya guna, upaya untuk melakukan perubahan dan perbaikan tersebut perlu dilandasi dengan analisis yang mendalam (diagnosis) demi memperoleh informasi dan pemahaman yang akurat tentang kondisi dan latar belakang yang menyebabkan munculnya anak jalanan. Lebih dari itu mengatasi persoalan anak jalanan membutuhkan sebuah komitmen yang benar-benar serius yang kemudian diwujudkan dalam program aksi bersama yang lebih konkrit dan kon- 
tekstual sebagaimana diungkapkan oleh koordinator anak jalanan Dinas Sosial DIY, Bapak Subakir (Wawancara 02 Mei 2016). Upayaupaya itu terangkum dalam suatu pembangunan yang disebut pembangunan kesejahteraan sosial.

Pembangunan kesejahteraan sosial tersebut bukan hanya tanggung jawab pemerintah, akan tetapi menjadi tanggung jawab bersama masyarakat. Masyarakat akan bertindak sebagai pelaksana utama, sedangkan pemerintah akan menetapkan regulasi atau peraturan serta mekanisme untuk menangani anak jalanan. Hal ini sesuai dengan amanat Undangundang Dasar 1945, negara harus bertanggung jawab mewujudkan kesejahteraan, dan dipertegas dengan lahirnya Undang-undang nomor 11 tahun 2009 (Presiden Republik Indonesia, 2009) tentang kesejahteraan sosial dimana pemerintah memiliki mandat yang lebih kuat daripada masyarakat maupun dunia usaha dalam penyelenggaraan kesejahteraan sosial (pasal 24).

Mewujudkan amanat Undang-undang Dasar 45 dan Undang-Undang Nomor 11 Tahun 2009, pemerintah Daerah Istimewah Yogyakarta mengeluarkan berbagai kebijakan yang salah satunya adalah Peraturan Daerah Provinsi DIY No 6 tahun 2011 Tentang Perlindungan Anak yang Hidup di Jalan. Tujuan dari Perda ini adalah untuk menggerakan seluruh masyarakat, lembaga sosial, dan lembaga pemerintah yang terkait untuk bekerja sama dalam menangani anak yang hidup di jalan, yang adalah amanah dan karunia Tuhan Yang Maha Esa, yang dalam dirinya melekat hak-hak untuk memperoleh kehidupan yang layak sebagaimana anak pada umumnya (Pemerintah Daerah Provinsi DIY, 2011). Terpenuhinya hak-hak anak secara memadai dapat menjamin terwujudnya kondisi fisik, psikis, dan sosial yang wajar serta selanjutnya mendukung kesehatan pertumbuhan dan perkembangan anak (Sitompul \& Retnowati, 2014, p. 2).

Penelitian ini bertujuan untuk mengevaluasi implementasi Perda Nomor 6 Tahun 2011 yang dilakukan oleh Dinas Sosial DIY sebagai lembaga Negara yang berfungsi untuk melakukan usaha kesejahteraan sosial dalam tugas dan tanggung jawab pelayanannya. Fokus evalusinya terletak pada upaya pemenuhan hak-hak dan kebutuhan anak jalanan. Diharapkan penelitian ini dapat bermanfaat dalam memahami realitas anak jalanan sehingga mampu menemukan solusi yang lebih baik dalam menangani anak jalanan.

\section{METODE PENELITIAN}

Penelitian ini adalah penelitian evaluasi dengan menggunakan pendekatan deskriptif kualitatif sebagai pendekatan utama dan didukung dengan pendekatan deskriptif kuantitatif. Model evaluasi yang digunakan dalam penelitian ini adalah model evaluasi Discrepancy (kesenjangan) yang dikembangkan oleh Malcom Provus. Model evaluasi kesenjangan berangkat dari asumsi bahwa untuk mengetahui kelayakan suatu program, evaluator dapat membandingkan antara apa yang seharusnya dan diharapkan terjadi (standar) dengan apa yang sebenarnya terjadi (performance) sehingga dapat diketahui ada tidaknya kesenjangan (discrepancy) antara keduanya. Dengan kata lain, model evaluasi ini digunakan oleh peneliti untuk mengukur besarnya kesenjangan antara Peraturan Daerah Nomor 6 Tahun 2011 (standar) dengan upaya pemenuhan hak-hak dan kebutuhan anak jalanan oleh Dinas Sosial DIY (performance).

Penelitian evaluasi ini dilakukan di Dinas Sosial DIY sebagai lembaga pemerintah yang mengimplementasikan Perda No 6 Tahun 2011 Tentang Perlindungan Anak yang Hidup di Jalan. Selain dinas sosial, peneliti juga mengambil data di RPS (Rumah Perlindungan Sosial), dan pada enam LKSA (Lembaga Kesejahteraan Sosal Anak) sebagai lembaga operasional yang bekerjasama dengan Dinas Sosial dalam upaya memenuhi hak-hak dan kebutuhan anak jalanan. Penelitian ini dilaksanakan dari tanggal 2 Mei hingga 11 Juni 2016. Dalam tenggang waktu ini, peneliti turun ke lapangan setiap hari untuk mengumpulkan data baik melalui wawancara, observasi, maupun melalui aktifitas penelitian lainnya.

Dalam penelitian ini responden diambil secara purposive baik responden yang berada di dinas sosial, RPS dan LKSA, maupun anak jalanan. Reponden yang diambil terdiri dari 3 orang staf seksi perlindungan anak jalanan pada Dinas Sosial, 2 orang pengasuh di RPS dan 13 reponden yang dipilih dari enam LKSA. Untuk memperdalam hasil penelitian, peneliti juga mewawancarai 4 orang anak jalanan, 2 orang yang berada di LKSA dan 2 orang anak jalanan yang beraktifitas di perempatan lampu merah Sagan. 
Data yang dibutuhkan dalam penelitian ini dikumpulkan melalui beberapa metode, yakni; observasi, wawancara, angket, dan dokumentasi. Instrumen yang digunakan dalam penelitian ini adalah peneliti sebagai instrumen pengumpulan data yang utama (teknik penelitian kualitatif), dan intrumen pembantu yang terdiri dari pedoman observasi berupa check list, pedoman wawancara, angket dan dokumen-dokumen. Observasi dilakukan untuk melihat secara langsung proses dan mekanisme pemenuhan hak dan kebutuhan anak jalanan. Responden yang diwawancarai terdiri dari 10 orang, yakni: Bapak Subakir (Koordinator Anak Jalanan); Ibu Lilis Sulistiyowati (Staf Seksi Perlindungan Anak); Ibu Retno Trihandayani (Pengasuh RPS); Bapak Yosua Lapudooh (Ketua Rumah Impian); Ibu Berlin Tandirerung (Pengasuh Rumah Impian); dan Mba Sri Yuni Shobiyati (Pengasuh Anak Mandiri). Peneliti juga mewawancarai 4 orang anak jalanan, yakni; Agus (LKSA Anak Mandiri); Lintang Prasasti (LKSA Rumah Impian); Ambar dan Dadang (Anak Jalanan Lampu Merah Sagan). Angket digunakan untuk mengetahui informasi mengenai komponen input, proses dan produk yang dibagikan kepada 13 orang pengasuh di LKSA. Butir-butir pertanyaan berjumlah 35 butir yang terdiri dari 10 butir pada komponen input, 11 butir pada komponen proses, dan 14 butir pada komponen produk. Skala pengukuran dalam setiap butir pertanyaan menggunakan skala Likert dengan 4 kategori jawaban yakni: Sangat Baik/Sangat Setuju, Baik/Setuju, Cukup Baik/Cukup Setuju, Kurang Baik/Kurang Setuju. Teknik dokumentasi digunakan untuk mengumpulkan sejumlah informasi, yakni Perda Nomor 6 Tahun 2011, Peraturan Gubernur Daerah Istimewah Yogyakarta Nomor 31 Tahun 2013 tentang Tata Cara Penjangkauan dan Pemenuhan Hak Anak yang Hidup di Jalan, Laporan Hasil Pemutakhiran data PMKS (Penyandang Masalah Kesejahteraan Sosial) dan PSKS (Potensi dan Sumber Kesejahteraan Sosial) Tahun 2014 (Pemerintah Daerah Provinsi DIY, 2014), dan foto-foto.

Validitas instrumen menggunakan validitas isi (content validity). Instrumen yang diukur validitas isinya adalah lembar observasi lembar wawancara, dan angket (Kuesioner). Dalam membuktikan validitas isi pada angket, peneliti menggunakan validitas tampang. Hal ini dilakukan karena jumlah responden lebih seidikit dari jumlah butir yang digunakan. Uji validitas isi dilakukan dengan metode validasi ahli atau experts judgement. Estimasi reliabilitas instrumen angket menggunakan pendekatan konsistensi internal. Teknik pengestimasiannya menggunakan formula Cronbach Alpha, estimasi reliabilitasnya adalah $\geq 0,7$. Dari hasil perhitungan diketahui bahwa nilai reliabilitas setiap komponen evaluasi yang diukur lebih besar dari standar yang telah ditetapkan yakni 0,7 sehingga memenuhi kriteria reliabilitas alat pengumpul data.

Tabel 1. Ringkasan Hasil Perhitungan Reliabilitas Angket

\begin{tabular}{|c|c|c|c|}
\hline No & Komponen & $\begin{array}{l}\text { Cronbach } \\
\text { Alpha }\end{array}$ & Reliabilitas \\
\hline \multicolumn{4}{|c|}{ Evaluasi Input } \\
\hline 1 & SDM & 0,781 & Reliabel \\
\hline 2 & $\begin{array}{l}\text { Disposisi } \\
\text { Implentor }\end{array}$ & 0,810 & Reliabel \\
\hline 3 & $\begin{array}{l}\text { Sarana dan } \\
\text { prasarana }\end{array}$ & 0,831 & Reliabel \\
\hline 4 & $\begin{array}{l}\text { Sumber Daya } \\
\text { Finansial }\end{array}$ & 0,883 & Reliabel \\
\hline \multicolumn{4}{|c|}{ Evaluasi Proses } \\
\hline 5 & $\begin{array}{l}\text { Respons } \\
\text { Implementor }\end{array}$ & 0,730 & Reliabel \\
\hline 6 & $\begin{array}{l}\text { Perencanaan dan } \\
\text { Waktu } \\
\text { Pelaksanaan }\end{array}$ & 0,815 & Reliabel \\
\hline 7 & Strategi & 0,901 & Reliabel \\
\hline \multicolumn{4}{|c|}{ Evaluasi Produk } \\
\hline 8 & $\begin{array}{l}\text { Pemenuhan Hak } \\
\text { Identitas }\end{array}$ & 0,772 & Reliabel \\
\hline 9 & $\begin{array}{l}\text { Pemenuhan Hak } \\
\text { Pengasuhan }\end{array}$ & 0,817 & Reliabel \\
\hline 10 & $\begin{array}{l}\text { Pemenuhan Hak } \\
\text { Pendidikan }\end{array}$ & 0,712 & Reliabel \\
\hline 11 & $\begin{array}{l}\text { Pemenuhan Hak } \\
\text { Kesehatan }\end{array}$ & 0,867 & Reliabel \\
\hline 12 & $\begin{array}{l}\text { Pemenuhan Hak } \\
\text { Kebutuhan Dasar }\end{array}$ & 0,867 & Reliabel \\
\hline
\end{tabular}

Keabsahan data kualitatif dilakukan melalui beberapa pengujian, yakni uji kredibilitas, transferabilitas, dependabilitas, dan konfirmabilitas. Uji kredibilitas dibuktikan memelalui beberapa teknik, yakni observasi partisipatoris, triangulasi, dan penggunaan bahan refrensi. Observasi partisipatoris dilakukan untuk menciptakan kedekatan dengan responden di Dinas Sosial, RPS, LKSA, dan anak jalanan. Teknik triangulasi yang digunakan Volume 6, No 1, June 2018 
adalah triangulasi sumber (Koordinator anak jalanan, staf penanganan anak jalanan, pengasuh di RPS dan LKSA, dan anak jalanan), triangulasi teknik (wawancara, observasi, dokumentasi, dan angket), dan triangulasi waktu (wawancara dan observasi dilakukan pada waktu dan tempat yang berbeda). Untuk menyempurnakan dan memperkuat uji kredibilitas, peneliti menggunakan kamera dan alat perekam wawancara sebagai bahan refrensi, yakni untuk merekam wawancara dan untuk mengabaikan gambar-gambar yang dibutuhkan. Uji transferabilitas dilakukan dengan mendeskripsikan hasil penelitian dalam bentuk laporan yang sistematis, jelas, terperinci, dan dapat dipercaya. Uji dependabilitas dilakukan dengan mengaudit seluruh proses penelitian. Audit dimulai dengan menentukan masalah/ fokus, memasuki lapangan, menentukan sumber data, melakukan analisis data, melakukan uji keabsahan data, dan membuat kesimpulan. Pengujian konfirmabilitas dilakukan sebagai bentuk transparansi peneliti untuk mengungkapkan secara terbuka tentang proses penelitian sehingga memungkinkan pihak lain untuk memberikan penilaian terhadap hasil penelitian ini. Langkah yang diambil oleh peneliti adalah melakukan konsultasi dengan peneliti ahli dan mempublikasikan hasil penelitian ini dalam Jurnal.

Teknik analisis data yang digunakan adalah teknik analisis data deskriptif kualitatif dan deskriptif kuantitatif. Data dari hasil wawancara, observasi dan dokumentasi dianalisis secara kualitatif yakni; reduksi data, display data, dan dilajutkan dengan pengambilan kesimpulan. Data yang diperoleh melalui angket dianalisis dengan cara kuantitatif untuk menghitung presentase jawaban responden dan jumlah responden pada setiap kategori jawaban yang diberikan. Hitungan data kuantitatif dibantu dengan menggunakan program SPSS.21.

Kriteria keberhasilan yang digunakan dalam penelitian evaluasi ini dikembangkan berdasarkan kajian teori implementasi kebijakan tentang faktor-faktor yang mempengaruhi implementasi kebijakan seperti sumber daya manusia dan finasial, ketersediaan sarana dan prasana pendukung, disposisi implementor, respons implementor, perencanaan, pelaksanaan serta strategi yang digunakan, dan dari Peraturan Daerah No 6 Tahun 2011 tentang Perlindungan Anak yang Hidup di Jalan yang meliputi pemenuhan hak identitas, hak peng- asuhan, hak pendidikan, hak kesehatan, dan hak atas kebutuhan dasar.

\section{HASIL PENELITIAN DAN PEMBAHASAN}

\section{Evaluasi Input}

Evaluasi input dilakukan untuk mengetahui sejauh mana tingkat kesiapan dinas sosial dalam memenuhi hak-hak dan kebutuhan anak jalanan sesuai dengan Peraturan Daerah Nomor 6 Tahun 2011. Komponen-komponen input yang dievaluasi terdiri dari Sumber Daya Manusia, Sarana dan Prasarana, Sumber Daya Finansial, dan Disposisi Implementor. Data dan informasi terkait komponen input diperoleh melalui wawancara, observasi, dokumentasi, dan angket.

\section{SDM (Sumber Daya Manusia)}

Evaluasi pada komponen SDM dilakukan terhadap 6 staf yang bekerja pada dinas sosial, 2 pengasuh pada Rumah Perlindungan Sosial (RPS) dan 13 pengasuh anak jalanan di 6 LKSA (Lembaga Kesejahteraan Sosial Anak). Keenam staf yang bekerja pada bagian seksi perlindungan anak terdiri dari satu tenaga Magister Administrasi dan lima tenaga sarjana yang terdiri dari tiga Sarjana Sosial, satu Sarjana Pendidikan (Bimbingan dan Konseling), dan satu Sarjana Sains. Dua pengasuh di RPS berlatar belakang pendidikan sarjana dan diploma. Sedangkan pengasuh yang mendampingi anak jalanan di 6 LKSA terdiri dari pekerja sosial yang berlatar belakang pendidikan sarjana dengan pengalaman kerja di atas lima tahun. Koordinator anak jalanan Bapak Subakir mengakui ketersediaan SDM yang baik dan berkualitas sangat mempengaruhi upaya pemenuhan hak dan kebutuhan anak jalanan (Bapak Subakir: Wawancara 11 Mei 2016). Terdapat beberapa faktor yang mempengaruhi kualitas SDM dalam memberi perlindungan dan memenuhi hak-hak dan kebutuhan anak jalanan. Faktor-faktor tersebut meliputi faktor pengalaman kerja, faktor kemampuan dalam memahami watak dan karakter anak jalanan, kemampuan dalam merangkul, kemampuan menciptakan rasa nyaman, dan kemampuan dalam membangun komunikasi yang efektif pada saat melayani dan memenuhi hak-hak dan kebutuhan anak jalanan. Berdasarkan data yang dihasilkan melalui wawancara dan observasi, dinas sosial secara keseluruhan telah menyediakan 
SDM yang baik dan berkualitas dalam memenuhi hak-hak dan kebutuhan anak jalanan. Hasil wawancara dan observasi didukung dengan hasil analisis angket dimana dari 13 responden sebanyak 84,6\% atau jawaban 11 responden yang berada pada kategori baik atau memiliki kualitas sumber daya manusia yang baik. Angka ini sekaligus menunjukan bahwa Dinas Sosial memiliki sumber daya yang baik dalam memenuhi hak-hak dan kebutuhan anak jalanan. Dinas sosial mengakui, kualitas sumber daya manusia yang ada sangat dipengaruhi oleh lamanya pengalaman kerja dan tingginya komitmen yang dimiliki dalam memenuhi hakhak dan kebutuhan anak jalanan.

\section{Disposisi Implementor}

Evaluasi untuk mengetahui disposisi implementor dilakukan terhadap 6 orang staf yang bekerja pada dinas sosial, 2 orang pengasuh pada Rumah Perlindungan Sosial (RPS) dan 13 pengasuh anak jalanan di 6 LKSA yang bekerja sama dengan dinas sosial dalam upaya memberi perlindungan sosial kepada anak jalanan. Komponen disposisi implementor melingkupi kejujuran, komitmen dan sifat demokratis (kemampuan dalam membangun kerja sama dengan pihak lain). Hasil wawancara dan observasi menunjukan bahwa, kejujuran, komitmen dan sifat demokratis (kemampuan dalam membangun kerjasama dengan pihak lain) dibangun berdasarkan harapan dan keinginan yang kuat untuk mengatasi persoalan anak jalanan, sebagaimana diungkapkan Bapak Subakir, koordinator perlindungan anak jalanan.

Memang kita harus memiliki sikap yang jujur, komitmen yang mendalam, dan memiliki kemampuan untuk bekerja sama dalam menangani anak jalanan. Komitmen yang dibangun bersama tersebut mengarahkan pandangan kita seutuhnya pada anak yang dalam kualifikasi tertentu disebut sebagai pandangan yang bersifat profestik terhadap anak (Wawancara: 11 Mei 2016).

Hasil wawancara, dan observasi kemudian didukung dengan hasil analisis angket. Hasil analisis angket menunjukkan bahwa, dari 13 responden sebanyak $69,2 \%$ atau jawaban 9 responden menunjukan kategori baik atau memiliki tingkat kejujuran, komitmen dan ke- mampuan bekerjasama yang baik. Kejujuran, komitmen dan sifat demokratis dibangun berdasarkan harapan dan keinginan yang kuat untuk mengatasi persoalan yang dihadapi anak jalanan.

\section{Sarana dan Prasarana}

Informasi tentang ketersediaan sarana dan prasarana diperoleh melalui wawancara, observasi, dokumentasi. Responden yang diwawancarai adalah Bapak Subakir, koordinator penanganan anak jalanan. Observasi difokuskan pada ketersediaan sarana dan prasarana di RPS, LKSA Rumah Impian, dan LKSA Anak Mandiri. Perlengkapan sarana dan prasarana yang disediakan oleh dinas sosial sudah dikatakan baik sebagaimana yang terlihat melalui observasi dan. Sarana dan prasarana yang disediakan di RPS terdiri dari tiga kamar tidur yakni satu untuk laki-laki, satu untuk wanita dan satu ruangan antara untuk anak jalanan yang berkebutuhan khusus. Di setiap ruangan tidur terdiri dari, satu kamar mandi dan toilet, dua tempat tidur besar dan bertingkat, satu buah meja, tiga buah kursi, dua buah lemari dan satu buah kipas angin. RPS juga menyediakan kamar makan berukuran luas yang dilengkapi dengan meja panjang dan belasan kursi. Terdapat satu dapur umum untuk memasak. Sedangkan tempat penampung air terdiri dari enam buah viber berukuran besar. RPS juga menyediakan halaman yang sangat luas sebagai tempat bermain anak. Sedangkan untuk trasnportasi (antar-jemput anak) disediakan satu mobil mini bus. Untuk kenyamanan, RPS menyediakan dua pos satpam yakni di pintu masuk dan di antara kamar tidur dan kamar makan anak jalanan. Rumah tersebut juga dikelilingi dengan tembok setinggi dua meter di bagian depan dan tiga meter di bagian belakang. Sedangkan untuk LKSA lainnya seperti rumah singgah, panti dan shelter, bantuan sarana dan prasarana diberikan dinas sosial dalam bentuk bantuan finansial sebagai danan operasional kelembagaan yang digunakan sesuai dengan kebutuhan lembaga tersebut. Secara umum sarana dan prasarana yang disediakan oleh dinas sosial sudah dikatakan baik.

\section{Sumber Daya Finanansial}

Informasi tentang ketersediaan sumber daya finansial diperoleh melalui wawancara, observasi, dokumentasi dan angket. Infor- 
masi yang diperoleh melalui wawancara menjelaskan bahwa sumber daya finasnsial yang digunakan dinas sosial dalam memenuhi hakhak dan kebutuhan anak jalanan berasal dari APBD dan APBN (Bapak Subakir: Wawancara 11 Mei 2016). Besarnya jumlah asupan dana dari APBD dalam setahun sebesar Rp517.329.200 (Lima ratus tujuh belas juta, tiga ratus dua puluh sembilan ribu, dua ratus rupiah). APBD juga menyediakan dana operasional untuk setiap LKSA yang tergabung dalam tim dengan dinas sosial sebesar Rp85.000.000/tahun (Delapan puluh lima juta). Sedangkan dana dari APBN sebesar Rp324.000.000/tahun (Tiga ratus dua puluh empat juta/tahun). Dana yang berasal dari APBN ini disalurkan melalui rekening anak. Secara keseluruhan dana yang digunakan untuk menangani anak jalanan kurang lebih sebesar Rp. 926.329.200/tahun (Sembilan ratus dua puluh enam juta, tiga ratus dua puluh sembilan ribu, dua ratus rupiah/tahun). Dinas sosial mengakui besarnya sumber daya finansial yang dimiliki sudah mampu memenuhi hak dan kebutuhan anak jalanan dengan baik. Hal ini juga diakui oleh pengasuh anak jalanan di RPS dan LKSA yang dapat dilihat melalui hasil analisis angket. Hasil analisis angket menunjukan, dari 13 responden sebanyak 38,5 $\%$ atau jawaban 5 responden berada pada kategori sangat baik, 30,8 \% atau jawaban 4 responden berada pada kategori baik.

\section{Evaluasi Proses}

Evaluasi proses pada penelitian ini terdiri dari tiga komponen yakni komponen strategi, perencanaan dan wakru pelaksanaan, dan respons implementor. Ketiga komponen ini sangat menentukan tingkat kesuksesan dinas sosial dalam memenuhi hak-hak dan kebutuhan anak jalanan. Data dan informasi terkait komponen input diperoleh melalui wawancara, observasi, dokumentasi, dan angket. Responden yang diwawancarai terdiri dari dua orang, yakni Bapak Subakir (Koordinator Perlindungan Anak Jalanan) dan Ibu Sri Yuni Shobiyati (Pengasuh LKSA Anak Mandiri).

Evaluasi untuk mengetahui respons implementor dilakukan terhadap 2 orang pengasuh pada Rumah Perlindungan Sosial (RPS) dan 11 pengasuh anak jalanan di 6 LKSA yang bekerja sama dengan dinas sosial dalam upaya memberi perlindungan sosial kepada anak jalanan. Komponen respons implementor me- lingkupi ketegasan, keseriusan, dan perasaan senang yag ditunjukan pengasuh pada waktu menangani anak jalanan. Respons implementor dapat dilihat melalui tingginya tingkat partisipasi staf dan pengasuh anak jalanan dalam mengikuti sidang atau rapat mengenai anak jalanan (Observasi: 12 Mei 2016). Wujud keseriusan juga ditunjukan dengan kehadiran mereka yang selalu tepat waktu pada berbagai kegiatan sebagaimana yang diakui oleh Bapak Subakir.

Terus terang, teman-teman itu komitmennya sangat tinggi. Saya yakin dinas sosial tidak mungkin dapat melaksanakan tugasnya dengan baik tanpa bantuan dan komitmen dari teman-teman di lapangan. Salah satu contoh komitmen teman-teman adalah ketika melakukan koordinasi penjangkauan. Kita tidak perlu pakai undangan resmi, cukup dengan WA. Semuanya datang tepat waktu (Wawancara 11 Mei 2016).

Keseriusan dalam menangani anak jalanan kemudian diwujudnyatakan melalui penjangkauan. Para staf yang bekerja di lapangan menunjukan komitmennya dengan menjalankan tugasnya dalam situasi dan kondisi apapun. Hasil wawancara dan observasi didukung dengan analisis angket dimana dari 13 responden sebanyak 69,2\% atau jawaban 9 responden berada pada kategori baik atau menjalankan tugasnya tegas, serius dan senang hati.

Berdasarkan hasil analisis data melalui wawancara dan observasi, upaya pemenuhan hak-hak dan kebutuhan anak jalanan oleh dinas sosial telah dilaksanakan sesuai dengan target, waktu, dan perencanaan yang telah dibuat. Hasil wawancara dan observasi didukung dengan analisis angket dimana dari 13 responden sebanyak 76,9\% atau jawaban 10 responden berada pada kategori baik, yakni telah memenuhi hak dan kebutuhan anak jalanan dengan baik sesuai dengan target, waktu dan perencanaan yang telah dibuat.

\section{Perencanaan dan Waktu Pelaksanaan}

Target utama dinas sosial dalam mengimplementasikan peraturan daerah nomor 6 tahun 2011 adalah bebas anak jalanan pada tahun 2016. Berdasarkan hasil observasi di lapangan, target ini dapat dikatakan tercapai 
setelah berkaca pada jumlah anak jalanan yang semakin berkurang baik anak jalanan yang beraktifitas di lampu merah ataupun anak jalanan yang beraktifitas pada tempat-tempat umum lainnya. Berkurangnya jumlah anak jalanan di jalan merupakan indikasi bahwa dinas sosial bersama LKSA telah menangani anak jalanan dengan baik, setidaknya ada bukti bahwa anak jalanan tidak lagi sering terlihat di jalanan. Kalaupun masih ada satu atau dua anak yang beraktifitas di jalan, hal itu dapat dipahami mengingat besarnya daya tarik kota Yogyakarta sebagai daerah yang selalu didatangi oleh anak-anak dari berbagai wilayah yang berbeda.

\section{Strategi}

Berdasarkan hasil analisis data melalui wawancara dan observasi, upaya pemenuhan hak-hak dan kebutuhan anak jalanan oleh dinas sosial telah dilaksanakan sesuai dengan strategi dan mekanisme yang jelas. strategi yang telah dibuat. Hasil wawancara dan observasi didukung dengan analisis angket dimana dari 13 responden sebanyak $61,5 \%$ atau jawaban 8 responden berada pada kategori baik atau telah memenuhi hak dan kebutuhan anak jalanan dengan baik dan efektif sesuai dengan cara dan mekanisme yang tepat. Strategi dan mekanisme khusus yang dipakai dinas sosial adalah dengan melakukan kerjasama yang baik dan produktif bersama pihak-pihak yang terkait. Sedangkan dalam tataran operasionalnya, dalam memenuhi hak-hak dan kebutuhan anak jalanan, dinas sosial bersama lembaga-lembaga terkait akan meningkatkan jadwal penjangkauan yang kemudian dilanjutkan dengan assesmen. Awal mula diimplemntasikannya Peraturan Daerah Nomor 6 Tahun 2011, penjangkauan dilakukan sebulan sekali. Setelah setahun berjalan strategi ini tidak memberikan hasil yang maksimal. Hal inilah yang kemudian mendorong dinas sosial bersama LKSA untuk mengubah strategi penjangkauan menjadi satu sampai tiga kali dalam seminggu. Dengan demikian jumlah penjangkauan yang dilakukan dinas sosial bersama LKSA dalam satu bulan adalah enam belas kali. Strategi ini kemudian berdampak dengan semakin berkurangnya anak yang beraktifitas di jalan. Setelah melakukan penjangkaun, langkah selanjutnya adalah melakukan assesmen terhadap anak jalanan yang berhasil diajak ke RPS dan
LKSA. Assesmen dilakukan untuk bisa mengetahui identitas, kondisi dan kebutuhan anak. Hasil assesmen membantu dinas sosial bersama LKSA dalam memenuhi hak-hak dan kebutuan anak jalanan.

\section{Evaluasi Produk}

Komponen-komponen pada bagian produk yang dievaluasi pada penelitian ini terdiri dari pemenuhan hak-hak dan kebutuhan anak jalanan. Hak-hak dan kebutuhan tersebut antara lain; pemenuhan hak identitas, pemenuhan hak atas pengasuhan, pemenuhan hak kesehatan, pemenuhan hak pendidikan, dan pemenuhan hak atas kebutuhan dasar.

\section{Pemenuhan Hak Identitas}

Berdasarkan data yang dihasilkan melalui wawancara dan observasi menunjukan bahwa, upaya pemenuhan hak indentitas anak jalanan oleh dinas sosial DIY masih dikategorikan cukup atau belum dilaksanakan dengan baik dan maksimal. Hasil wawancara dan observasi ini didukung dengan hasil analisis angket dimana dari 13 responden hanya 15,4\% atau jawaban 2 responden yang berada pada kategori baik atau telah memenuhi hak identitas anak jalanan dengan baik. Sebaliknya terdapat 10 responden atau 76,9\% jawaban reponden masih berada pada kategori cukup baik. Dengan demikian pemenuhan hak identitas anak jalanan belum terpenuhi dengan baik.

Rendahnya ketercapaian pemenuhan hak identitas tidak secara lugas menunjukan kegagalan dinas sosial dalam memenuhi hak identitas anak jalanan. Data dan realitas di lapangan menunjukan bahwa pemenuhan hak identitas adalah bagian tersulit yang ditemui oleh dinas sosial bersama LKSA dalam upaya memenuhi hak dan kebutuhan anak jalanan. Hal ini dapat dijelaskan melalui beberapa hal: Pertama, tujuan utama dinas sosial bersama LKSA dalam menangani dan mendampingi anak jalanan adalah untuk mengembalikan anak kepada keluarga sebagai pengasuh terbaik. Dinas sosial bersama LKSA pada tempat pertama berperan untuk memfasilitasi agar anak jalanan bisa dikembalikan ke keluarga dan daerah asal mereka. Kedua, tidak ada satupun anak yang mengantongi identitas legal seperti akta pencatatan sipil. Ketika melakukan penjangkauan terhadap anak jalanan, kondisi awal anak jalanan belum jelas khususnya me- 
ngenai asal usul, keluarga dan usia anak. Pada waktu dijangkau anak jalanan kerapkali memberikan nama yang bukan nama sebenarnya. Penelusuran asal usul anak dilakukan oleh dinas sosial bersama LKSA setelah informasi yang diberikan dianggap benar dan meyakinkan. Ketiga, usia anak jalanan rata-rata masih di bawah 17 tahun. Usia anak yang pada umumnya masih di bawah 17 tahun menutup kemungkinan bagi dinas sosial bersama LKSA untuk dapat mengurus KTP anak jalanan. Hal ini dikarenakan aturan kepemilikan KTP hanya untuk warga yang berusia 17 tahun ke atas atau yang sudah menikah.

\section{Pemenuhan Hak atas Pengasuhan}

Berdasarkan data yang dihasilkan melalui wawancara dan observasi, upaya pemenuhan hak anak jalanan atas pengasuhan dikategorikan baik atau telah dilaksanakan dengan baik. Hasil wawancara dan observasi ini didukung dengan hasil analisis angket dimana dari 13 responden sebanyak $46,2 \%$ atau 6 responden menjawab baik. Sisanya, 38,5\% atau 5 responden menjawab cukup baik dan $15,4 \%$ atau 2 responden menjawab kurang baik. Data-data ini sekaligus menunjukan bahwa upaya pemenuhan hak pengasuhan anak jalanan dikategorikan baik atau terimplementasi dengan baik.

Tujuan utama dalam pengasuhan adalah mengembalikan anak ke keluarga dan daerah asal anak. Hal ini dikarenakan sentralitas peran dan tanggung jawab keluarga sebagai pengasuh terbaik bagi setiap anak. Keluarga sebagai tempat asal anak selalu menjadi target dinas sosial bersama LKSA dalam mengembalikan anak setelah melakukan assesmen dan mengetahui asal usul dan identitas anak. Ada beberapa mekanisme yang harus dilewati. Pertama, menghubungi pedukuhan, lurah serta RT dan RW setempat. Hasil penelusuran ke tingkat kelurahan, RT dan RW membantu untuk memastikan tempat tinggal anak. Kedua, mengembalikan anak jalanan ke keluarga. Apabila ada anak jalanan yang tidak bisa dikembalikan ke keluarga karena belum ada keluarga yang mengakuinya, maka pengasuhan anak tersebut menjadi tanggung jawab dinas sosial bersama LKSA sampai ada yang mengadopsi atau anak tumbuh dewasa. Dalam kaitannya dengan pengasuhan yang dilakukan oleh lembaga, dinas sosial akan bekerjasama dengan lembaga penanganan dan pendampingan anak seperti panti dan pesantren. Lembaga yang dipilih harus disesuaikan dengan kondisi dan kebutuhan anak. Jadi, selama diasuh di panti dan di pesantren, dinas sosial tetap berperan sebagai pengasuh dan bertanggung jawab untuk memenuhi hak dan kebutuhan anak jalanan.

\section{Pemenuhan Hak Pendidikan}

Berdasarkan data yang dihasilkan melalui wawancara dan observasi, upaya pemenuhan hak anak jalanan atas pendidikan dikategorikan baik. Hasil wawancara dan observasi ini didukung dengan hasil analisis angket mengenai upaya pemenuhan hak pendidikan anak jalanan, dimana dari 13 responden sebanyak 46,2 \% atau 6 responden menjawab baik. Sisanya, 30,8\% atau 4 responden menjawab sangat baik dan $23,1 \%$ atau 3 responden menjawab cukup baik. Dapat disimpulkan dinas sosial dan LKSA telah memenuhi hak pendidikan anak jalanan dengan baik.

Hak pendidikan anak jalanan diperoleh melalui pendidikan layanan khusus atau pendidikan kejar paket. Pendidikan layanan khusus tersebut diselenggarakan oleh LKSA. Setiap LKSA yang menyelenggarakan pendidikan layanan khusus memiliki program kelompok belajar bersama. Kelompok belajar bersama ini dilakukan tiga kali dalam seminggu, yakni hari senin, rabu dan jumat pada pukul tiga sampai pukul lima sore. Dalam memperlancar aktivitas belajar, LKSA telah menyediakan perpustakaan (foto dilampirkan) yang dilengkapi dengan berbagai buku bacaan. Sedangkan untuk target jalur pendidikan formal cukup sulit disebabkan latar belakang usia dan kondisi anak jalanan itu sendiri. Contohnya anak jalanan yang berusia belasan tahun tapi belum melewati jalur Sekolah Dasar tidak mungkin mengikuti jalur pendidikan formal. Selain itu kondisi anak yang sudah terbiasa dengan kehidupan jalan yang vulgar dan tanpa aturan memberi ketidaknyamanan kepada anak yang lainnya di sekolah. Label anak jalanan terkadang mengganggu siswa-siswi yang lainnya.

\section{Pemenuhan Hak Kesehatan}

Sehat adalah kondisi yang harus dimiliki oleh semua manusia, tidak terkecuali anak jalanan. Pemenuhan hak kesehatan meliputi upaya promotif, preventif, kuratif dan rehabilitatif. Berdasarkan data yang dihasilkan 
melalui wawancara dan observasi, upaya pemenuhan hak anak jalanan atas kesehatan sudah dilakukan dengan sangat baik oleh dinas sosial bersama LKSA. Hasil wawancara dan observasi ini didukung dengan hasil analisis angket dimana dari 13 responden sebanyak $46,2 \%$ atau 6 responden menjawab sangat baik. Sisanya, 30,8\% atau 4 responden menjawab baik dan 23,1\% atau 3 responden menjawab cukup baik. Data-data ini sekaligus menunjukkan bahwa upaya pemenuhan hak kesehatan anak jalanan dikategorikan sangat baik atau terimplementasi dengan sangat maksimal.

Dinas sosial mengakui bahwa, pemenuhan hak kesehatan termasuk dalam upaya pemenuhan hak anak yang tidak terlalu sulit dilakukan. Kemudahan tersebut dikarenakan kebijakan daerah yang tertuang dalam Peraturan Daerah Nomor 6 Tahun 2011 yang memberi wewenang kepada pemerintah, baik pemerintah pusat maupun pemerintah daerah dan/atau pemerintah kota untuk memberi jaminan biaya pengobatan bagi anak jalanan yang sakit. Rekomendasi kebebasan biaya dijadikan sebagai jaminan kesehatan pengganti jamkessos. Surat rekomendasi tersebut dialamatkan kepada Gubernur. Dengan adanya surat rekomendasi, setiap anak jalanan yang sakit dan terdaftar di dinas sosial dan LKSA akan dibiayai oleh pemerintah daerah. Di samping berbagai kemudahan pembiayaan, informasi yang didapatkan dari anak jalanan melalui wawancara juga mengatakan bahwa anak jalanan tidak terlalu sering mengalami gangguan kesehatan. Sakit yang dialami anak jalanan mumnya hanya sebatas flu dan batuk pilek. Oleh karena itu, pelayanan kesehatan bagi anak jalanan yang sakit bisa dilayani di LKSA dengan memberikan obat yang direkomendasikan dokter sambil memperhatikan makanan dan waktu istrahat. Walaupun demikian situasi tersebut tidak mengurangi keseriusan pengasuh untuk memperhatikan dan menjaga anak jalanan yang sakit.

\section{Pemenuhan Hak atas Kebutuhan Dasar}

Pemenuhan hak atas kebutuhan dasar meliputi sandang, pangan, dan tempat tinggal. Dinas sosial bersama LKSA memiliki tugas dan tanggung jawab dalam memperhatikan pemenuhan hak dan kebutuhan dasar anak jalanan. Berdasarkan data yang dihasilkan melalui wawancara dan observasi, upaya pemenuhan kebutuhan dasar anak jalanan dikategorikan baik. Hasil wawancara dan observasi ini didukung dengan hasil analisis angket dimana dari 13 responden sebanyak $69,2 \%$ atau 9 responden menjawab baik. Sisanya, 23,1\% atau 3 responden menjawab sangat baik dan $7,7 \%$ atau 1 responden menjawab cukup baik. Pemenuhan kebutuhan dasar itu sendiri dibagi ke dalam tiga kelompok yakni; makanan dan minuman, pakayan dan tempat tinggal.

Pertama, pemenuhan kebutuhan akan makanan dan minuman (pangan). Dalam memenuhi kebutuhan akan makanan dan minuman, dinas sosial menyediakan dana sebesar Rp.170.000.000 (seratus tujuh puluh juta rupiah). Dana sebesar Rp170.000.000 (seratus tujuh puluh juta rupiah) digunakan untuk memenuhi kebutuhan gizi anak jalanan yang ada di LKSA. Sebaliknya, untuk pemenuhan gizi bagi anak jalanan yang belum tinggal di LKSA, dinas sosial akan memberikan bantuan satutiga juta rupiah dalam setahun. Di samping itu, untuk anak jalanan yang sudah ada di RPS, pemenuhan gizinya akan diperhatikan oleh staf yang ada di RPS. Berdasarkan hasil observasi ketersediaan makanan dan minuman di RPS dikatakan baik karena menu makanan harian anak jalanan selalu dilengkapi dengan lauknya. Jadi dapat disimpulkan bahwa pemenuhan kebutuhan makanan dan minuman sudah terpenuhi dengan baik.

Kedua, pemenuhan kebutuhan akan pakaian (sandang). Pemenuhan kebutuhan akan pakaian untuk anak jalanan di RPS dan LKSA sudah dikategorikan baik. Kebutuhan akan pakaian seperti baju, celana, sandal dan sepatu sudah disediakan dengan baik. Pakaian untuk anak jalanan di RPS dan LKSA sudah terjamin, mulai dari baju, celana, dan sepatu. Jenis pakaian yang disediakan terdiri dari pakaian kerja dan pakaian khusus. Jenis pakaian yang termasuk dalam kategori pakaian khusus adalah celana dalam, singlet, atau kolor. Sedangkan yang dikategorikan dalam pakaian kerja adalah pakaian resmi harian. Khusus untuk perempuan, RPS dan LKSA menyediakan pakaian khusus dan hal-hal yang berkaitan dengan kebutuhan perempuan termasuk softex. Jadi anak diperlakukan sebagaimana anak-anak pada umumnya, sesuai dengan kebutuhannya.

Ketiga, pemenuhan kebututuhan akan tempat tinggal. Berdasarkan hasil observasi di RPS dan LKSA, tempat tinggal yang digunakan untuk anak jalanan sudah dikatan baik dan layak. Terdapat rumah sebagai tempat tinggal Volume 6, No 1, June 2018 
yang nyaman untuk anak jalanan. Juga disediakan tempat tidur beserta kasurnya sesuai dengan kebutuhan anak. LKSA dan RPS juga menyediakan kamar mandi dan WC permanen, ruangan tamu serta hal-hal yang dibutuhkan selayaknya sebuah rumah. Di samping itu, LKSA dan RPS juga sudah menyediakan tempat tidur dan kasur cadangan untuk anak-anak yang baru. Singkatnya untuk kondisi tempat tinggal anak jalanan sudah dikatakan baik.

\section{Mekanisme Pemenuhan Hak-hak dan Kebutuhan Anak Jalanan}

Mekanisme yang digunakan dalam upaya pemenuhan hak identitas anak jalanan terdiri dari tiga langkah yakni assesmen, identifikasi, dan klarifikasi. Assesmen dilakukan untuk mengetahui identitas dan kebutuhan anak. Assesmen dilanjutkan dengan identifikasi. Identifikasi bertujuan untuk memperjelas indentitas anak berdasarkan laporan yang diberikan anak. Apabila identitas anak sudah jelas, langkah selanjutnya adalah melakukan klarifikasi dengan orang tua atau keluarga dekat, menghubungi RT, RW, Pedukuhan dan Kelurahan setempat. Apabila keluarga dan institusi-institusi yang telah dihubungi mengakui kebenaran indentitas dan segala informasi yang diberikan anak, maka mekanisme selanjutnya adalah mengembalikan anak ke keluarga dan daerah asalnnya sehingga dapat mengurus kartu keluarga dan kartu indetitas anak.

Mekanisme yang dilakukan oleh dinas sosial dalam memenuhi hak atas pengasuhan disesuaikan dengan jenis pengasuhan yang diberikan. Upaya pengasuhan yang diperjuangkan oleh dinas sosial bersama LKSA adalah pengasuhan yang dilakukan oleh orang tua atau keluarga dekat. Dalam mengembalikan anak ke keluarga, dinas sosial pertama-tama akan melakukan assesmen terhadap anak untuk dapat menggali informasi yang tepat tentang keluarga dan asal usul anak. Informasi yang diperoleh melalui assesmen akan diklarifikasi dengan menghubungi keluarga dan instansi terkait di daerah asal anak. Langkah selanjutnya adalah melakukan reunifikasi yakni dengan mengundang keluarga ke dinas sosial atau dengan mengembalikan anak ke keluarga yang memiliki kendala secara finansial. Khusus bagi anak jalanan yang bertemu dengan keluarganya akan dialihkan kepada pengasuhan alternatif atau pengasuhan kelembagaan. Mekanisme yang dilakukan adalah bekerjasama dengan lembaga penanganan dan pendampingan anak seperti panti dan pesantren. Lembaga yang dipilih disesuaikan dengan kondisi dan kebutuhan anak. Selama diasuh di panti dan pesantren, dinas sosial tetap berperan sebagai pengasuh dan bertanggung jawab untuk memenuhi hak dan kebutuhan anak.

Mekanisme yang digunakan dalam memenuhi hak pendidikan anak jalanan adalah melalui pendidikan layanan khusus atau pendidikan kejar paket. Pendidikan layanan khusus tersebut diselenggarakan oleh beberapa LKSA. Setiap LKSA yang menyelenggarakan pendidikan layanan khusus memiliki program kelompok belajar bersama. Kelompok belajar bersama ini dilakukan tiga kali dalam seminggu, yakni hari senin, rabu dan jumat pada pukul tiga sampai pukul lima sore. Dalam memperlancar aktivitas belajar, LKSA telah menyediakan perpustakaan yang dilengkapi dengan berbagai buku bacaan.

Mekanisme pemenuhan hak kesehatan anak jalanan dibagi ke dalam dua bentuk pelayanan yakni pelayanan kesehatan pada tingkat dasar dan pelayanan kesehatan pada tingkat rujukan. Pelayanan kesehatan pada tingkat dasar diberikan melalui puskesmas dan jejaringannya. Pelayanan pada tingkat dasar ini diperuntukan bagai anak jalanan yang mengalami gangguan kesehatan pada tingkat dasar seperti demam, batuk atau pilek. Selanjutnya pelayanan kesehatan anak akan dilakukan di LKSA oleh pengasuh yakni dengan memperhatikan makan, jam istirahat dan keteraturan dalam mengkonsumsi obat sebagaimana yang direkomendasikan oleh puskesmas. Pelayanan pada tingkat rujukan diberikan kepada anak yang mengalami gangguan kesehatan serius, termasuk dalam hal ini adalah anak yang akan dioperasi. Pada tingkat rujukan pelayanan diberikan melalui rumah sakit umum milik pemerintah, pemerintah daerah, dan swasta sesuai dengan surat rekomendasi dari puskesmas. Biaya kesehatan untuk anak jalanan yang masih berada di bawah pengasuhan LKSA atau dari akan ditanggung oleh pemerintah melalui surat rekomendasi yang diajukan oleh dinas sosial sebagai pengganti jamkessos.

Mekanisme dalam memenuhi kebutuhan dasar anak jalanan diberikan melalui RPS dan LKSA untuk anak yang belum dikembalikan ke orang tua atau keluarga pengganti. Tugas RPS dan LKSA adalah memenuhi kebutuhan dasar anak seperti pakayan, makanan 
dan minuman, serta tempat tinggal yang bersih dan nyaman. Sedangkan untuk anak yang telah dikembalikan ke keluarga, pemenuhan kebutuhan dasarnya diberikan melalui bantuan langsung tunai sebesar dua sampai tiga juta rupiah kepada anak dalam setahun. Bantuan langsung tunai diawali dengan membentuk TRC (Team Reaksi Cepat) sebagai pemenuhan tanggap darurat. TRC ini menangani kasuskasus khusus seperti anak dari orang tua yang benar-benar tidak mampu. Bantuan tersebut dilanjuti dengan pendampingan khusus yakni untuk membimbing anak agar dapat menggunakan dana tersebut dengan baik dan benar.

\section{Hambatan-hambatan dalam Memenuhi Hak-hak dan Kebutuhan Anak Jalanan dan Solusinya}

Hambatan dalam memenuhi hak identitas anak jalanan disebabkan dua faktor yakni anak yang disabilitas (bisu dan tuli) dan anak yang tidak jujur. Dinas Sosial dan LKSA mengalami kesulitan untuk menanyakan identitas, keluarga, dan daerah asal anak. Usaha yang dilakukan oleh dinas sosial dan LKSA untuk berkomunikasi dengan anak jalanan yang disabilitas adalah dengan mendatangkan tenaga ahli untuk menerjemahkan informasi yang diberikan anak. Informasimasi yang diperoleh dari anak jalanan akan diklarifikasi dengan pihak keluarga dan lembaga terkait (RT, RW, Kelurahan dan Pedukuhan) untuk mengecek kebenarannya. Selain anak jalanan yang disabilitas, anak jalanan yang tidak jujur kerapkali memberikan kesulitan tersendiri bagi dinas sosial dan pengasuh dalam upaya memenuhi hak identitasnya. Umumnya, ketika baru pertama kali diasuh dari jalan, anak jalanan biasanya memberikan informasi-informasi yang tidak tepat ketika ditanyai mengenai identitasnya. Meningkatkan kesabaran adalah cara terbaik dalam menangani anak jalanan yang tidak jujur. Membutuhkan waktu dua hingga tiga hari untuk bisa meyakinkan anak akan tujuan baik yang sedang diusahakan oleh dinas sosial dan pengasuh. Setelah merasa nyaman barulah anak jalanan tersebut memberikan informasi yang jelas mengenai nama dan daerah asalnya.

Hambatan utama dalam melakukan pengasuhan adalah mengembalikan anak jalanan ke keluarga sebagai pengasuh utama. Hal ini dikarenakan adanya penolakan dari dalam diri anak untuk dikembalikan ke keluarga. Kategori anak jalanan seperti ini kebanyakan berasal dari keluarga broken home dan keluarga yang kurang mampu. Rumah menjadi tempat yang tidak menarik lagi bagi anak, akibatnya anak tidak lagi punya keinginan untuk kembali ke rumah. Masalah sesuangguhnya bukan terletak pada anak tetapi pada orang tua atau keluarga yang tidak mampu menciptakan situasi yang nyaman dalam keluarga. Mengatasi persoalan ini, dinas sosial bersama LKSA melakukan pendekatan langsung dengan keluarga untuk sesegera mungkin mengatasi masalah dalam rumah sehingga tidak mengorbankan anak. Di samping itu keluarga juga akan diberi peringatan yakni mencabut hak asuh anak apabila masih membiarkan anak turun ke jalan. Sedangkan usaha lainnya adalah memberikan sanksi administratif berupa perintah mengikuti program pembinaan bagi orang tua anak. Usaha ini memang tidak selalu memberikan hasil yang maksimal, sebab mengubah mindset orang tua lebih sulit daripada mengubah mindset anak jalanan itu sendiri. Mengembalikan anak jalanan dari keluarga yang kurang mampu juga cukup sulit. Hal ini dikarenakan peralihan tugas yang dilakukan anak di jalan sebagai sumber keuangan bagi keluarga. Solusi yang dilakukan adalah memberikan bantuan langsung tunai sebesar dua hingga tiga jutah dalam setahun. Dinas juga memberikan bimbingan dan bantuan usaha kecil menegah yang disertai dengan program pendampingan dan bimbingan bagi anak dan keluarganya.

Hak pendidikan yang diberikan kepada anak jalanan pada umumnya diselenggarakan melalui pendidikan layanan khusus atau kejar paket. Permasalahan atau hambatan yang seringkali dihadapi pengasuh dalam mengupayakan pendidikan layanan khusus ini adalah meningkatkan komitmen dan motivasi anak untuk belajar dan mengikuti jadwal yang telah dibuat. Menghadapi keadaan anak jalanan seperti ini para pengasuh menggunakan pendekatan khusus yakni menghabiskan lebih banyak waktu bersama anak jalanan. Semakin banyak waktu yang dihabiskan bersama mereka, semakin mereka yakin akan niat baik para pengasuh dalam menolong mereka. Keakraban dan rasa nyaman yang anak jalanan miliki memberi ruang kepada para pengasuh untuk membuka mindset mereka sehingga bisa diajak untuk belajar.

Hambatan yang dialami dalam memenuhi hak kesehatan anak jalanan umumnya berasal dari kondisi internal anak jalanan seperti 
sulitnya menjaga kebersihan diri, kebersihan lingkungan, pola makan dan waktu istrahat yang teratur. Dalam banyak situasi anak jalanan masih terbiasa dengan kehidupan di jalan yang kotor dan tidak teratur. Demikainpun halnya dengan anak jalanan pria yang masih susah menghentikan kebiasaan merokok. Solusi yang dilakukan pengasuh adalah dengan bersikap tegas dan konsisten dengan aturan yang telah dibuat. Setiap anak yang tidak mengikuti aturan akan ditegur dan diberi sanksi untuk membersihkan rumah. Selain itu, pengasuh juga berusaha untuk menggunakan pendekatan yang persuasif yakni dengan menjalin kedekatan dengan anak jalanan. Kedekatan memberi ruang kepada pengasuh untuk bisa mengintervensi kehidupan anak jalanan.

Sebagaimana anak pada umumnya, anak jalanan juga memiliki kebutuhan khsusus baik untuk makanan dan minuman. Di sisi lain yang namanya dapur umum dengan sendirinya bersifat umum. Di dapur umum, semua menunya dimasak sesuai dengan menu yang sudah dijadwalkan secara terperinci. Mengatasi masalah ini, maka menu juga harus diatur sesuai dengan kebutuhan anak. Kalau ada anak yang berkebutuhan khusus maka akan dilayani sesuai dengan kebutuhannya. Sedangkan hambatan untuk pemenuhan kebutuhan akan tempat tinggal terletak pada masalah pemeliharaan. Kesulitan terbesar dinas sosial bersama LKSA adalah menyadarkan anak jalanan untuk bisa menjaga fasilitas yang ada dengan baik. Dalam banyak kesempatan anak jalanan dapat dengan mudah merusak fasilitas yang ada. Mengatasi persoalan seperti ini, dinas sosial bersama LKSA telah menyediakan beberapa fasilitas cadangan seperti, tempat tidur, meja, kursi, lemari dan juga kasur. Di samping untuk mengganti yang rusak, fasilitas cadangan juga disediakan untuk mengatasi kelebihan anak yang akan diasuh di LKSA.

\section{SIMPULAN}

Hasil evaluasi implementasi Perda Nomor 6 Tahun 2011 menunjukkan pemenuhan hak dan kebutuhan anak jalanan yang telah dilakukan dengan baik oleh Dinas Sosial DIY. Hasil evalusi ini terbukti dengan tidak ditemukannya kesenjangan yang besar antara program dan ketentuan yang dibuat pemerintah melalui Perda Nomor 6 Tahun 2011 (standar) dengan upaya pemenuhan hak dan kebutuhan anak jalanan (performance) yang diupayakan oleh dinas sosial bersama LKSA. Hal ini dapat terlihat jelas pada hasil evaluasi produk seperti pemenuhan hak pendidikan, kesehatan, pengasuhan dan kebutuhan dasar telah dilakukan dengan maksimal sehingga menunjukan hasil yang baik. Pada hasil evaluasi produk, hanya bagian pemenuhan hak identitas yang belum memberikan hasil yang maksimal atau masih berada pada kategori cukup baik. Walaupun demikian, upaya pemenuhan hak dan kebutuhan anak jalanan tidak terlepas dari berbagai hambatan. Hambatan-hambatan yang ditemui pada dasarnya berasal dari kondisi dan latar belakang anak jalanan itu sendiri. Terdapat tiga hambatan utama yang dialami oleh Dinas Sosial dalam menangani anak jalanan. Hambatan-hamabatan tersebut antara lain: (1) Anak jalanan yang disabilitas/cacat fisik. Hal ini dikarenakan pola komunikasi yang tidak efektif antara anak dan pengasuh. Usaha yang dilakukan oleh dinas sosial adalah mendatangkan tenaga ahli. Tenaga ahli yang diundang akan membantu menerjemahkan setiap informasi yang diberikan anak jalanan; (2) Anak jalanan yang tidak jujur dengan asal usul dan identitas asli mereka. Bersabar dan bersikap rendah hati adalah cara yang dilakukan oleh Dinas Sosial ketika berhadapan dengan anak yang tidak jujur. Anak jalanan akan memberikan identitas yang benar ketika sudah merasa nyaman dan mulai yakin dengan tujuan baik yang dilakukan pengasuh; (3) Anak jalanan yang berkebutuhan khusus. Berkebutuhan khusus di sini lebih kepada kebutuhan akan makanan. RPS dan LKSA biasanya menyediakan jenis makanan yang sama untuk semua anak jalanan. Pada kenyataannya ada beberapa anak jalanan yang memiliki masalah dengan makanan tententu (pantang). Dengan demikian Dinas Sosial bersama LKSA dan RPS harus menyediakan makanan khusus untuk anak jalanan yang berkebutuhan khusus.

Berdasarkan hasil temuan data dan informasi selama penelitian, peneliti menemukan tiga saran penting yang akan mejadi bahan pertimbangan dinas sosial dalam memenuhi hak dan kebutuhan anak jalanan. Beberapa saran yang perlu dipertimbangkan tersebut adalah sebagai berikut: Pertama. Memisahkan tempat anak jalanan dengan penyandang kesejahteraan sosial lainnya. Hal ini membantu memudahkan pengasuh dalam memenuhi hak dan kebutuhna anak jalanan. Dengan ditempatkannya anak jalanan pada tempat yang terpi- 
sah, perhatian dinas sosial kepada anak jalanan menjadi terfokus, sehingga assesmen yang diberikan kepada anak jalanan menjadi lebih efektif. Kedua. Sebelum dikembalikan ke keluarga atau orang tua, dinas sosial harus benarbenar memastikan anak jalanan dalam keadaan siap untuk dikembalikan. Mengembalikan anak sebelum mendapatkan bimbingan yag mendalam membuka kemungkinan bagi anak untuk kembali ke jalan. Hal ini dikarenakan belum adanya bimbingan atau pengarahan mendalam yang memberi kesadaran kepada anak untuk tidak lagi kembali ke jalan. Sebab pada kenyataannya, banyak anak yang kembali ke jalanan setelah dikembalikan ke orang tua atau daerah asalnya. Ketiga. Bimbingan terhadap anak jalanan di RPS dan LKSA minimal 3 bulan sebelum dikembalikan ke orang tua.

\section{DAFTAR PUSTAKA}

Boakye-Boaten, A. (2016). Surviving in the streets; the story of a street girl from Ghana. International Journal of Humanities AndSocial Science, 1(18).

Lusk, M. W. (1989). Street children programs in Latin America. The Journal of Sociology \& Social Welfare, 16(1).

Nugroho, R. (2004). Kebijakan sosial untuk negara berkembang. Yogyakarta: Pustaka Pelajar.

Pemerintah Daerah Provinsi DIY. Peraturan
Daerah Provinsi DIY Nomor 6 Tahun 2011 tentang Perlindungan Anak yang Hidup di Jalan (2011).

Pemerintah Daerah Provinsi DIY. (2014). Laporan hasil pemutakhiran data PMKS (penyandang masalah kesejahteraan sosial) dan PSKS (potensi dan sumber kesejahteraan sosial) Tahun 2014.

Presiden Republik Indonesia. Undang-undang Republik Indonesia Nomor 11 Tahun 2009 tentang Kesejahteraan Sosial (2009).

Rafi, S., Ali, M., \& Aslam, M. A. (2012). The problem of street children: case study of Sargodha City. American International Journal of Contemporary Research, 2(2). Retrieved from http://www.aijcrnet.com/journals/Vol_2 _No_2_February_2012/23.pdf

Sitompul, N., \& Retnowati, T. H. (2014). Evaluasi program penjangkauan anak jalanan melalui lembaga kesejahteraan sosial anak di Kabupaten Bantul Yogyakarta. Jurnal Evaluasi Pendidikan, 2(1).

Soetomo. (2013). Masalah sosial dan upaya pencegahannya. Yogyakarta: Pustaka Pelajar.

Suyanto, B. (2010). Masalah sosial anak. Jakarta: Media Kencana Group. 